\title{
Aquatic and Semi-Aquatic Flora (Monocotyledons) Of Lalitpur District (U.P.), India.
}

\author{
${ }^{1}$ Vijay Kumar, ${ }^{2}$ P.K. Singh \\ ${ }^{1}$ Department of Botany, Singhania University, Jhunjhunu (Rajasthan), India. \\ ${ }^{2}$ Department of Botany Pt. J.N.P.G. College, Banda (U. P.), India.
}

\begin{abstract}
The distribution of 73 aquatic and semi-aquatic angiospermic species belonging to 39 genera and 19 families collected from all three tahsils (Lalitpur, Mahroni and Talbahat) of Lalitpur district of Uttar-Pradesh are enumerated. The members of family Cyperaceae exhibit their dominance followed by Hydrocharitaceae, Commelinaceae and Aracaceae with 33, 5, 4 and 4 species respectively.

Key Words: Aquatic and semi-aquatic Flora, Monocotyledons, Lalitpur.
\end{abstract}

\section{Introduction}

Aquatic and semi-aquatic plants are those species which normally stands in water and must grow for at least a part of their life cycle in water, either completely submerged or emersed [1]. Aquatic angiosperms are very remarkable forms of plant life, mainly on account of the fact that due to aquatic habit [2], in which they spend most of their lives, they are practically unaffected by climatic and seasonal changes, or atleast much less affected than lands plants. For this reason it is possible to study such plants more or less through out the year. Lalitpur District is rich in aquatic and semi-aquatic vagetation due to presence of artificial and natural lakes , nullahas, and ponds, such as Matatila, Jamni, Rohini, Govind Sagar, Sajnam dam, hajariya shankerji ka mansarover, Shahpur pond, Poorakala pond, Shahjad river and dulaawan pond. The District is situated in South-west of Uttar Pradesh in between 24.11-25.77 N and 78.79 E. This is most backward District of bundelkhand.

Except for the classical work Subramanyam [3] of there was no serious effort to study the aquatic and semi-aquatic angiosperms of India. It is against this back drop that the present study was undertaken to explore the Lalitpur district especially to make an exhaustive inventory of aquatic and semi-aquatic angiosperms of this area.

The present study was carried out during 2010 - 2012 in deferent seasons of the year. Many selected water bodies of the District in different Tehsils and places like Talbahat, Lalitpur, Mahroni (AllTehsils), Hinaota, Bijrautha, Paron, Bansi, Bar, Birdha and Madanpur were regularly surveyd. The plant species were collected in their flowering, fruiting or at fully mature stage. Attempts have been made to note down plant size, flower colour, fruit type, flowering period, habit and habitats, medicinal uses, common name and other characteristics. Plant specimens soon after the collection were labelled and placed in the polythene bags. Every time 4-5 specimens were collected. These plant specimens were carefully pressed between the news papers. After pressing, drying and poisoning the specimens were pasted on the herbarium sheets with fevicol. Voucher herbarium specimens were deposited in the department of Botany, Pt. J. N. P. G. College, Banda (U.P.). The plants were identified with the help of regional floras $[, 4,5,6,7]$ and other important publications mentioned in references. Ecology and distribution of these plants were described and families are arranged accordingly Bentham and Hooker's classification [8].

\section{Results And Discussion}

The results of the survey are given in Table-1 with ecological distribution common (C) and rare ( R ) in different tehsils Talbahat ( T ) Lalitpur (L) and Mahroni (M ). 
Aquatic And Semi-Aquatic Flora (Monocotyledons) Of Lalitpur District (U.P.), India.

Table-1 Aquatic and Semi-Aquatic plants (Monocotyledons) From Lalitpur District.

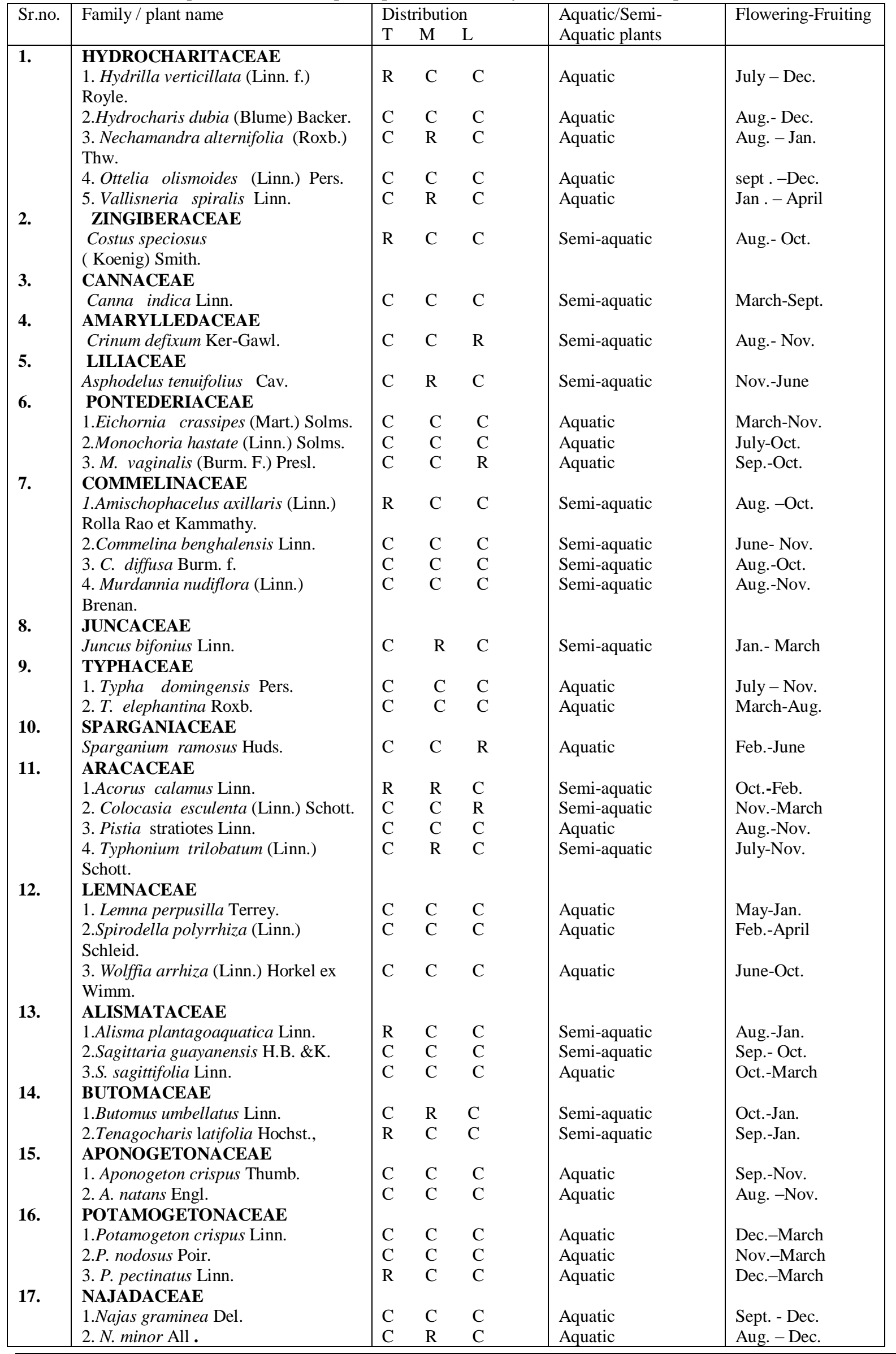


Aquatic And Semi-Aquatic Flora (Monocotyledons) Of Lalitpur District (U.P.), India.

\begin{tabular}{|c|c|c|c|c|c|c|}
\hline 18. & 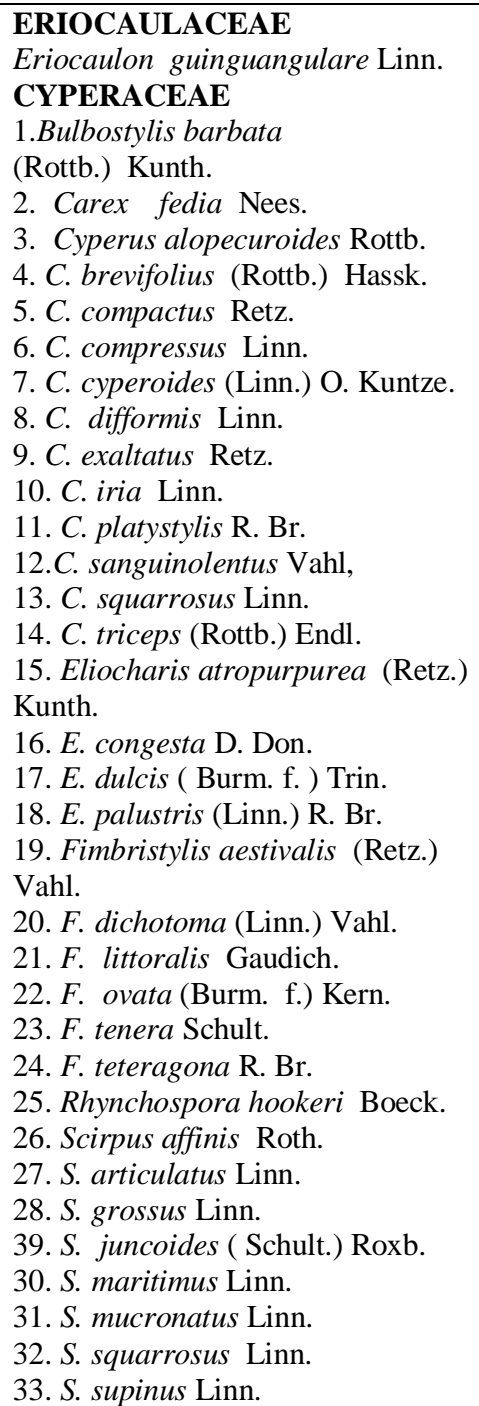 & $\begin{array}{l}\mathrm{C} \\
\mathrm{C} \\
\mathrm{C} \\
\mathrm{C} \\
\mathrm{C} \\
\mathrm{C} \\
\mathrm{C} \\
\mathrm{C} \\
\mathrm{C} \\
\mathrm{R} \\
\mathrm{C} \\
\mathrm{C} \\
\mathrm{C} \\
\mathrm{C}\end{array}$ & $\begin{array}{l}\mathrm{C} \\
\mathrm{C} \\
\mathrm{C} \\
\mathrm{C} \\
\mathrm{C} \\
\mathrm{C} \\
\mathrm{C} \\
\mathrm{C} \\
\mathrm{C} \\
\mathrm{C} \\
\mathrm{C} \\
\mathrm{C} \\
\mathrm{C} \\
\mathrm{C}\end{array}$ & $\begin{array}{l}\mathrm{C} \\
\mathrm{R} \\
\mathrm{C} \\
\mathrm{C} \\
\mathrm{C} \\
\mathrm{C} \\
\mathrm{C} \\
\mathrm{C} \\
\mathrm{C} \\
\mathrm{C} \\
\mathrm{C} \\
\mathrm{C} \\
\mathrm{C} \\
\mathrm{C}\end{array}$ & $\begin{array}{l}\text { Semi-aquatic } \\
\text { Semi-aquatic } \\
\text { Semi-aquatic } \\
\text { Semi-aquatic } \\
\text { Semi-aquatic } \\
\text { Semi-aquatic } \\
\text { Semi-aquatic } \\
\text { Semi-aquatic } \\
\text { Semi-aquatic } \\
\text { Semi-aquatic } \\
\text { Semi-aquatic } \\
\text { Aquatic } \\
\text { Semi-aquatic } \\
\text { Semi-aquatic } \\
\text { Semi-aquatic } \\
\text { Semi-aquatic } \\
\text { Semi-aquatic } \\
\text { Aquatic } \\
\text { Semi-aquatic } \\
\text { Semi-aquatic } \\
\text { Semi-aquatic } \\
\text { Semi-aquatic } \\
\text { Semi-aquatic } \\
\text { Semi-aquatic } \\
\text { Semi-aquatic } \\
\text { Semi-aquatic } \\
\text { Semi-aquatic } \\
\text { Semi-aquatic } \\
\text { Aquatic } \\
\text { Aquatic } \\
\text { Semi-aquatic } \\
\text { Aquatic } \\
\text { Semi-aquatic } \\
\text { Semi-aquatic }\end{array}$ & $\begin{array}{l}\text { Aug. - Nov. } \\
\text { July - Sep. } \\
\text { Feb. - April } \\
\text { Aug.- Nov. } \\
\text { March- Nov. } \\
\text { Aug. - Nov. } \\
\text { July - Oct. } \\
\text { Sep.-Oct. } \\
\text { Aug. - Jan. } \\
\text { Sept.-Dec. } \\
\text { Aug.- Dec } \\
\text { April- Sep. } \\
\text { July-Oct. } \\
\text { April-Dec. } \\
\text { July-Nov. } \\
\text { July- Nov. } \\
\text { Sep.-Dec. } \\
\text { Sept.-Jan. } \\
\text { Dec.-March } \\
\text { Aug. - Dec. } \\
\text { March- Dec. } \\
\text { Sept. - Nov. } \\
\text { Aug. -Dec. } \\
\text { Sept. - Nov. } \\
\text { Aug. -Oct. } \\
\text { Aug. -Oct. } \\
\text { Feb. - June } \\
\text { Oct.- March } \\
\text { July-Oct. } \\
\text { Aug. - Nov. } \\
\text { Feb.-June } \\
\text { Oct. -March } \\
\text { Sept. - Dec. } \\
\text { July-Nov. }\end{array}$ \\
\hline
\end{tabular}

III. Acknowledgment

Thanks are due to the Principal and head department of Botany, Pt J. N.P.G. College Banda for providing necessary facilities required for the present work.

\section{References}

[1] S.K. Srivstava. (2011). Plant Diversity and Conservation strategies of Uttar Pradesh. Phytotaxonomy Vol. $11: 45-62$.

[2] 2. R.S. Ambsht. (1990.) Ecology of wetland with particular references to asian- pacific region (Being published in the proceeding Volume) International Conf.on Asia Pacific Region.

[3] K. Subramanyam. (1962). Aquatic Angiosperms. CSIR. New Delhi.

[4] C.R. Babu. (1977).Herbaceous flora of Dehra Dun, CSIR, New Delhi.

[5] J.F. Duthie. (1963) (Rep. Ed.). Flora of Upper Gangetic Plain and the Adjecent Siwalic and Sub-Himalayan Tracts. 1-3 vols. Calcutta. India.

[6] M. B. Raizada.( 1976.) Supplement to the Duthie's Flora of the Upper Gangetic plain and of the adjacent Siwalik and Sub - Himalyan Tracts, Dehra-Dun.

[7] J. D.Hooker. (1872 -1897.) The flora of British India. London 7 vols. Repr. (Ed.)

[8] G.Bentham and J.D.Hooker (1862-1863). Genera plantarum, 3 vols. London.(Repr.Ed.) 